\title{
Tisztelt Kolléga!
}

Ez idáig egyedülálló kezdeményezés eredményét tartja a kezében. Tizennégy hazai orvostársaság közös munkájaként kialakított konszenzust a D-vitamin szerepéről a betegségek megelőzésében és kezelésében.

Joggal kérdezheti, mi indokolja, hogy pont erről a kérdésről folytassunk ilyen széles körü szakmai vitát, alakítsunk ki sok szempontból egységes álláspontot. A konszenzus megalkotását több indok is magyarázza:

- A D-vitamin-hiány az egyik legnagyobb egészségügyi kockázat. Gyakorisága Magyarországon 50-70\% közé tehető évszakoktól függően, habár magyarországi reprezentetatív felmérés még nem áll rendelkezésünkre.

- A D-vitamin (D-hormon) hatása szinte valamennyi szervrendszerben megnyilvánul, hiánya klinikailag fontos eltéréseket, betegségeket okoz.

- Kialakulása, anyagcseréje egyedülálló. Hiánya civilizációs betegség, vérszintje hazánkban évszakfüggó.

- A javasolt D-vitamin-dózisok szinte minden ajánlásban különbözőek. Az élelmiszer-hatóságok, az orvosi társaságok és az egyes szerzők egymástól lényegesen különböző adagú D-vitamin bevitelét javasolják. Legtöbbször a javaslatok nem tartalmazzák, hogy prevenciós vagy kezelési adagokról van-e szó, nem térnek ki az évszakok, az életkor vagy a testsúly jelentette különbségekre sem.

- Rendkívül sok félreértés alakult ki a szakmai köztudatban is. A D-vitaminnal kapcsolatos érdeklődés fokozódását sokszor egy kalap alá veszik a nem indokolt „vitamin-divathullámmal”, habár - mint tudjuk - a D-vitamin csak nevében vitamin. Sokan indokolatlanul félnek pótlásától, néhányan csodaszerként tekintenek rá.

A konszenzus célja, hogy szigorúan a rendelkezésre álló tudonyos eredmények alapján, a hazai viszonyokra adaptálva iránymutatást adjon a gyakorló orvosok kezébe.
Nemcsak a létrejöttében különleges, hanem szerkezetében is egyedülálló szakmai munkát tarthat a kezében az olvasó. A bizonyítékokon alapuló orvoslás irányelveit követő szakmai ajánlásokkal szemben itt nem osztályozzuk a rendelkezésre álló adatok tudományos erejét. Ennek oka, hogy számos betegségcsoport esetében kevés az információnk, inkább csak figyelemfelhívó, mint bizonyító erejű adatok állnak rendelkezésünkre. Ezek az adatok azonban - megítélésünk szerint - fontosak annak eldöntésében, hogy a D-vitamin pótlását alkalmazzuk-e. A konszenzus írásos összefoglalójának nagy részét tudományos eredmények ismertetése, értelmezése adja. Ennek szerkezete nem teljesen egységes, mert az egyes alfejezetek a különböző társaságok képviselőinek múvei, tükrözve társaságuk álláspontját. Sok esetben ezeknek a részeknek teljesen egységes szerkezetbe foglalása sértette volna az eredeti szöveg tartalmi részét is. A konszenzus végén található ajánlás a prevencióban, illetve a kezelésben alkalmazandó dózisokról sok hónapos egyeztetés eredménye. Scylla és Charybdis között próbáltunk elhajózni, megkeresni a mindenki számára elfogadható, még biztosan nem ártalmas, de már hatásos dózisokat. Hangsúlyozottan közös megegyezés alapján létrejött, mindenki számára elfogadható ajánlást alakítottunk ki. Tudjuk, hogy ezek az adagok az újabb adatok, vizsgálati eredmények alapján valószínúleg változni fognak. Éppen ezért a konszenzust minden két évben felújítjuk.

A közös munkában részt vevő kollégákkal és szakmai társaságokkal együtt reméljük, hogy munkánk eléri a célját és iránymutatást ad a gyakorló orvosok kezébe a D-vitamin-pótlással, -kezeléssel kapcsolatban.

Budapest, 2012. április 26.

Dr. Takács István, a konszenzus szervezője 